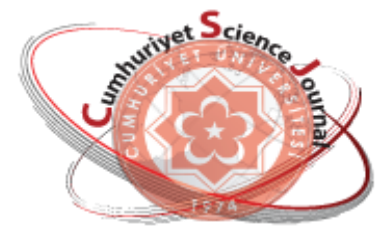

e-ISSN: $2587-246 X$

ISSN: $2587-2680$

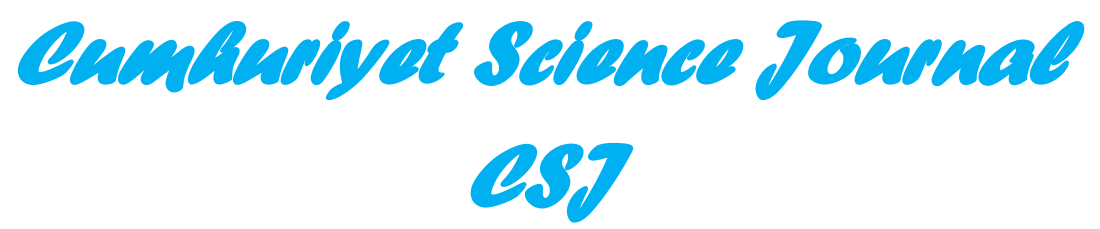

Cumhuriyet Sci. J., Vol.40-2(2019) 305-316

\title{
Interference-free determination of carmine in food samples using ultrasonic assisted cloud point extraction coupled with spectrophotometry
}

\author{
Adil ELIK ${ }^{1}$ \\ ${ }^{I}$ Cumhuriyet University, Faculty of Sciences, Department of Chemistry, TR-58140, Sivas, Turkey
}

Received: 22.11.2018; Accepted: 04.02.2019

http://dx.doi.org/10.17776/csj.486753

\begin{abstract}
In this study, a simple, green and cost effective method of extraction and preconcentration of carmine used as a food additive in some food samples was developed using ultrasonic assisted cloud point extraction (UA-CPE) before spectrophotometric determination. Carmine was extracted from the aqueous solution using polyoxyethylenesorbitan monolaurate (Tween 20) as the extraction solvent in presence of $\mathrm{Ni}(\mathrm{II})$ at $\mathrm{pH} 6.5$. Variables such as $\mathrm{pH}$, amount of metal, temperature, ultrasonic effect, solvent type, type and concentration of nanionic surfactant have been optimized in detail. Under the optimum conditions, the analytical characteristics of the method are as follows; linear working range 1.5-350 $\mu \mathrm{g} \mathrm{L}^{-1}$; the detection limit, $0.4 \mu \mathrm{g} \mathrm{L}^{-1}$; and preconcentration factor, 80. The relative standard deviation (RSD\%) obtained for the $10 \mu \mathrm{g} \mathrm{L}^{-1}$ concentration (n: 5) of carmine was 3.7\%. Recovery values for two different concentration levels were in the range of 94.8$104.7 \%$. The accuracy and precision of the method were evaluated by intra- and inter-day studies. Finally, the method has been successfully applied to the determination of carmine in various foods.
\end{abstract}

Keywords: Carmine, food samples, ultrasound assisted extraction, green chemistry, spectrophotometry.

\section{Spektrofotometri ile birleştirilmiş ultrasonik destekli bulutlanma noktası ekstraksiyonu kullanılarak gıda örneklerinde karminin girişimsiz tayini}

Özet. Bu çalışmada, bazı gıda örneklerinde, carmine'nin spektrofotometrik tayin öncesi basit, yeşil ve düşük maliyetli özelliklere sahip ultrasonik yardımlı bulut noktası ekstraksiyonu (UA-CPE) geliştirilmiştir. Carmine, pH 6.5'de Ni (II) varlı̆ğında ekstraksiyon çözücüsü olarak polioksietilensorbitan monolaurat (Tween 20) kullanılarak sulu çözeltiden özütlenmiştir. pH, metal miktarı, sıcaklık, ultrasonik etki, solvent tipi, nanyonik yüzey aktif madde türü ve konsantrasyonu gibi değişkenler en uygun şekilde optimize edilmiştir. Optimum koşullar altında, yöntemin analitik özellikleri aşağıdaki gibidir; doğrusal çalışma aralığı 1.5-350 $\mu \mathrm{g} \mathrm{L}{ }^{-1}$; tespit limiti, 0,4 $\mu \mathrm{g} \mathrm{L}^{-1}$; ve ön konsantrasyon faktörü, 80. Karminin $10 \mu \mathrm{g} \mathrm{L}^{-1}$ konsantrasyonu (n: 5) için elde edilen bağıl standart sapma (\% BSS) \% 3.7 idi. İki farklı konsantrasyon seviyesi için geri kazanım değerleri \% 94.8104.7 arasındaydı. Yöntemin doğruluğu ve kesinliği, gün içi ve günler arası çalışmalarla değerlendirildi. Son olarak, yöntem çeşitli gıdalarda karmin tayini için başarıyla uygulanmıştır.

Anahtar Kelimeler: Carmine, gıda örnekleri, ultrason destekli ekstraksiyon, yeşil kimya, spektrofotometri.

\section{INTRODUCTION}

Synthetic food dyes are used in different industries such as paper, textile, ink, plastics, cosmetics, pharmaceuticals, beverages and food. Food dyes

are widely used to make food more attractive and appetizing. Generally, food dyes have complex aromatic structures and are stable. Therefore, they

\footnotetext{
* Corresponding author. Email address: elik@cumhuriyet.edu.tr

http://dergipark.gov.tr/csj C2016 Faculty of Science, Sivas Cumhuriyet University
} 
are biodegradable. Carmine (E120), used as a food colouring, is a bright red pigment derived from the aluminium salt of carminic acid [1]. It is used as colouring pigments in cosmetic products such as pharmaceutical formulations, eye fir and lipstick as well as many different products such as carmine, fruit juices, ice cream, yogurt and sugar. Carmine, one of the synthetic food colors, is approved for use in the USA, Canada, Korea and the European Union [2]. Acceptable daily of carmine intake (ADI) is average $5 \mathrm{mg}$ based on body weight [3]. Although the amounts of carmine added to foods and drinks are strictly controlled, their use may exceed the tolerable limit. Therefore, it is very important to observe the carmine dye levels in high-consumption food products.

In recent years, the number of studies on this subject has witnessed the importance of this problem. For the analysis of food dyes fast, accurate and emphasizes the need to develop selective techniques. Until now, various methods like differential pulse polarography (DPP) [4], stripping voltammetry (SV) [5], high performance liquid chromatography (HPLC) [6], and spectrophotometry [7] have been proposed for the determination of carmine in food samples. Chromatography and polarography methods are not considered as green analytical methods due to the use of hazardous organic solvents in the chromatography and the reduction of mercury in the polarography [8]. On the other hand, HPLC and capillary electrophoresis (CE) methods are interpreted as more effective alternative methods. However, these methods are expensive, time consuming, and generates waste containing a high proportion of organic solvent [9]. Despite the high sensitivity of electroanalytical methods, its selectivity is low. Disadvantages of the stripping voltammetry (SV) include longer analysis times compared to spectroscopic methods, as well as interference that can lead to limitations [10]. UVvisible spectrometry is an important tool in this area, with a low weight and low cost. In addition, it is often used in many areas such as chemistry, food, and environment. There are two main limitations to the spectrometric determinations of food dyes. The first is the lower analytical quantity than the quantitative limits of the UV-visible spectrometry, and the other is the possible interference effect of other chemical species present in the samples. Preconcentration-separation methods such as solid phase extraction (SPE) [11,12], cloud point extraction (CPE) [13-16], solvent extraction (SE) [17], and ion exchange (IE) $[18,19]$ were widely used to solve these problems. The current trend in analytical chemistry, especially for quality control applications, is the development of methods that include environmentally friendly less reactive consumption. For this reason, the cloud point extraction (CPE) method, which uses surfactants for the separation and preconcentration of carmine, was used in the study. The basis of the CPE method depends on the non-ionic surfactant in the aqueous solutions becoming cloudy (forming miscellaneous) when heated to a temperature known as cloud point temperature [20]. The micelle solution, which is above the cloud point temperature, forms two separate phases as the small volume surfactant rich phase and the diluted aqueous phase [21]. By centrifugation, the surfactant-rich phase tube is collected at the bottom and the aqueous phase is separated by decantation. The surfactant phase which is then dissolved in a suitable solvent can be analyzed by a suitable technique. In addition, this method is an alternative to conventional liquid liquid extraction (LLE) due to its high enrichment factor, less desirable sample size, lower toxic reagent use, elimination of large amounts of organic solvents, use of non-toxic surfactants, safer, simpler and more economical [22].

Sonication is a powerful aid in accelerating the various steps of the analytical process especially extraction and sample preparation steps [24]. Ultrasonic energy is released at the end through a cavitation process, which involves evacuation of the formation and breakdown of microbubbles to high temperatures [24]. This energy is of great help in the pre-treatment of solid and liquid samples as it facilitates and accelerates operations such as the extraction of different chemical species (organic, biological, and inorganic compounds) from different samples such as biologicals, environmental and foods [25-28]. 
The purpose of this study, for the determination of carmine dye used in food samples, was to develop an analytical method that is selective, sensitive, consuming less reagents, and environmentally friendly. To achieve this goal, a combination of ultrasound-assisted cloud point extraction and spectrophotometry was used to provide environmental and low-reagent consumption. The factors affecting the efficiency of extraction were examined systematically. The proposed method was compared with some methods in the literature in terms of analytical properties. After validation of the method, the method was successfully applied to the determination of carmine in various food samples with satisfactory results.

\section{MATERIALS AND METHODS}

\subsection{Instrumentations}

Spectrophotometric analysis was performed on a double-beamed Shimadzu UV-1800 PC spectrophotometry (Kyoto, Japan) equipped with $1.0 \mathrm{~cm}$ quartz cells. The injection volume and detection wavelength were $500 \mu \mathrm{L}$ and $510 \mathrm{~nm}$, respectively. Ultrasonic bath (UCP-10 model, Seoul, Korea) was used for extraction of carmine and sample preparation. A Universal Hettich model centrifuge (London, UK) was used to separate the extract from the aqueous phase. All $\mathrm{pH}$ measurements were performed using a Selecta 2001 Sartorius model (North America) pH meter combined with a glass calomel electrode. A Labconco ultrapure water system (Kansas City, USA) was used to obtain ultra-pure water used in the experiments and $18.2 \mathrm{M} \Omega \mathrm{cm}^{-1}$ resistant water was obtained.

\subsection{Reagents}

All working reagents were purchased from Sigma (St. Louis, Mo., USA). Standard work solutions were prepared by gradual dilution of stock solutions. The stock carmin solution was prepared in ethanol-water $(50: 50, \mathrm{v} / \mathrm{v})$ at a concentration of $0.1 \mathrm{~mol} \mathrm{~L}^{-1}$ and stored at $4{ }^{\circ} \mathrm{C}$ in a refrigerator. The standard $\mathrm{Ni}$ (II) solution (1000 $\mathrm{mg} \mathrm{L}^{-1}$ ) was prepared by dissolving the nitrate salt in water. $5.0 \%(\mathrm{w} / \mathrm{v})$ polyoxyethylene-isobutyl monolaurate (Tween 20) was prepared by dissolving $5.0 \mathrm{~g}$ of Tween 20 in methanol using an ultrasonic bath and diluting to $100 \mathrm{~mL}$ with water. The phosphate- citrate buffer solution was prepared by mixing 35.2 $\mathrm{mL}$ of $0.2 \mathrm{~mol} \mathrm{~L}^{-1} \mathrm{Na}_{2} \mathrm{HPO}_{4}$ and $14.8 \mathrm{~mL}$ of 0.1 mol L $\mathrm{L}^{-1}$ citrate solutions for $\mathrm{pH}$ 6.5. Prior to the experiments, all vessels (glassware, low density and high density polyethylene bottles) were kept in $10 \%(\mathrm{v} / \mathrm{v}) \mathrm{HNO}_{3}$ for at least one day and then washed five times with ultrapure water.

\subsection{Sample preparation}

In order to investigate the feasibility of the developed method, some food samples (strawberries, rice, sour cherry, syrup, powdered drinks, biscuits and jellybeans) were randomly selected from the markets in Sivas/Turkey. Ultrasonically assisted extraction (UAE) method was used to prepare the selected samples for analysis. Sample preparation steps were performed as follows.

First, a mixer was used to homogenize 5.0 grams of food samples. These milled samples were then transferred to a $100 \mathrm{~mL}$ beaker and final volume was adjusted to $50 \mathrm{~mL}$ with pure water by adding $0.05 \mathrm{~mol} \mathrm{~L}^{-1} \mathrm{NaOH}$ solution. The extraction was performed by applying ultrasonic energy $(300 \mathrm{~W}$ at $40 \mathrm{kHz}$ ultrasound frequency) at room temperature in an ultrasonic bath until a clear solution was obtained [29]. The extract was then centrifuged at $4000 \mathrm{rpm}$ for 5 minutes, and the pore size was adjusted to $0.45 \mathrm{~mm}$ by filtration through a membrane filter.

\subsection{Ultrasonic assisted cloud point extraction}

The recommended procedure was resumed as follows. First, a $3 \mathrm{~mL}$ aqueous sample solution containing $50 \mu \mathrm{g} \mathrm{L}^{-1}$ carmine was added to a $50 \mathrm{~mL}$ centrifuge tube, and then $1.25 \mathrm{~mL}$ of phosphatecitrate buffer solution was added to adjust the $\mathrm{pH}$ of the sample solution to 6.5. After adjusting the $\mathrm{pH}, 2.5 \mathrm{~mL}$ of $10 \mathrm{mg} \mathrm{L}^{-1} \mathrm{Ni}$ (II) solution was added to form a hydrophobic complex with carmine, and the solutions were diluted to about $45 \mathrm{~mL}$ with distilled water. After waiting 2 minutes to form the appropriate complex (Carmine-Ni), $1.0 \mathrm{~mL}$ of $5.0 \%(\mathrm{w} / \mathrm{v}$ ) Tween 20 was added to the solution 
and the final volume was $50 \mathrm{~mL}$. The mixture was then sonicated in an ultrasonic bath for 10 minutes at $55{ }^{\circ} \mathrm{C}$ to provide cloudiness of the surfactant. The surfactant phase was separated from the aqueous phase by centrifugation at $4000 \mathrm{rpm}$ for 5 minutes. The upper aqueous phase was then withdrawn with a syringe. To reduce the viscosity of the surfactant rich phase, the remaining phase was added to $500 \mu \mathrm{L}$ of methanol and transferred to a quartz cell. Finally, the absorbance reactivated versus schooled at $510 \mathrm{~nm}$.

\section{RESULTS AND DISCUSSION}

\subsection{Optimization of UV detection wavelength}

To determine the wavelength of the complex, the absorption spectrum as a function of reactive vacancy and the carmine concentration was investigated in the wavelength range of 350-650 $\mathrm{nm}$. The studies were conducted under optimum conditions for three different concentrations of carmine.

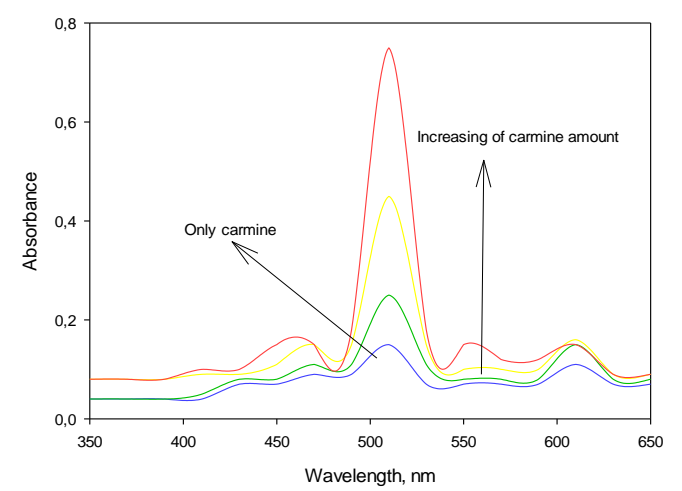

Figure 1. Spectra obtained depending on concentration of carmine $\left(10,50,100 \mu \mathrm{g} \mathrm{L}^{-1}\right)$ under optimal conditions

As can be seen in Figure 1, it is understood that in the presence of $\mathrm{Ni}$ (II) there is a large absorption peak at about $510 \mathrm{~nm}$ with a significant sensitivity difference and a linear relationship with the carmine concentration. Therefore, the absorbance measurements were continued at $510 \mathrm{~nm}$ to increase the detection sensitivity. This shows luminescence with a red shift of $65 \mathrm{~nm}$ with fluorescence-specific carminic acid ( $\lambda$ ex: $493 \mathrm{~nm}$, $\lambda \mathrm{em}: 593 \mathrm{~nm}$ ) with Al (III) ( $\lambda$ ex: $517 \mathrm{~nm}, \lambda \mathrm{em}: 582$ $\mathrm{nm}$ ) in contrast to the luminescence of carmine, which forms stable complexes with $\mathrm{Ni}$ (II) ions but does not cause any wavelength shift due to the effect of low energetic ligand [30]. In the aqueous mica medium, the absorption wavelength of the $\mathrm{NiL}_{2}{ }^{2-}$ or $\mathrm{H}_{2} \mathrm{Ni}_{2}$ complex in the presence of Tween 20 shifted to $13 \mathrm{~nm}$ due to $\mathrm{H}$-bonding, $\pi$ - $\pi$ staking and hydrophobic interactions.

\subsection{Optimization of extraction conditions}

In this study, the optimization of the variables that could affect the extraction efficiency was carried out by monitoring the recovery. Recovery for each variable was calculated according to the following formula.

Recovery, $\% \mathrm{R}=\frac{C_{\text {int }} . V_{\text {int }}-C_{\text {final }} \cdot V_{\text {final }}}{C_{\text {int }} \cdot V_{\text {int }}} 100$

The meanings of the indices in the form are as follows. $\mathrm{C}_{\mathrm{int}}$ : initial concentration, $\mathrm{V}_{\text {int }}$ : initial volume, $\mathrm{C}_{\text {final }}$ post-concentration, $\mathrm{V}_{\text {final }}$ final volume. For each optimal point worked, \% $\mathrm{R}$ is calculated according to the formula above. The amount at which the highest $\% \mathrm{R}$ ratio is obtained is chosen as the most appropriate value for that variable. The operating range and optimum value of each parameter are given in Table 1 .

Table 1. Optimization of analytical variables affecting the complex formation and extraction efficiency of carmine

\begin{tabular}{ccc}
\hline Parameters & Working Range & Optimum Value \\
\hline $\mathrm{pH}$ & $2.5-10.5$ & 6.5 \\
Ni(II) volume $\left(10 \mu \mathrm{g} \mathrm{L} \mathrm{I}^{-1}\right), \mathrm{mL}$ & $0.0-3.0$ & 2.5 \\
Tween 20 volume $(\% 5.0, \mathrm{a} / \mathrm{h}), \mathrm{mL}$ & $0.0-3.0$ & 1.0 \\
Sample volume, $\mathrm{mL}$ & $5-150$ & 40 \\
Equilibrium Temperature, ${ }^{\circ} \mathrm{C}$ & $25-70$ & 55 \\
Ultrasonic time, $\mathrm{dk}$ & $1-30$ & 10 \\
Centrifugal rate, $\mathrm{rpm}$ & $1000-4000$ & 4000 \\
Centrifugal time, $\mathrm{min}$ & $1-10$ & 2 \\
\hline
\end{tabular}


The first parameter to be optimized in the extraction procedure is the $\mathrm{pH}$ of the solution. Because the $\mathrm{pH}$ of the solution directly affects the chemical form of the reagents. The optimum $\mathrm{pH}$ value should be selected to form the complex containing analyte. For these reasons, the effect of $\mathrm{pH}$ on the recovery of Carmine was studied in the presence of $\mathrm{Ni}$ (II) in the range of 2.5-10.5. The results obtained are given in Figure 2 (a). From pH 2.5 to $6.5, \% \mathrm{R}$ rapidly increased, but there was no significant change from $\mathrm{pH} 6.5$ to 8.5 . There was a significant decrease in $\% \mathrm{R}$ at higher $\mathrm{pH}$ values. This decrease in extraction yield comes from the hydrolysis of $\mathrm{Ni}$ (II) ions. In further studies, the $\mathrm{pH}$ for the extraction of carmine was chosen as the optimal value of 6.5 and the $\mathrm{pH}$ adjustment was carried out with $0.1 \mathrm{~mol} \mathrm{~L}^{-1}$ phosphate-citrate buffer solution.
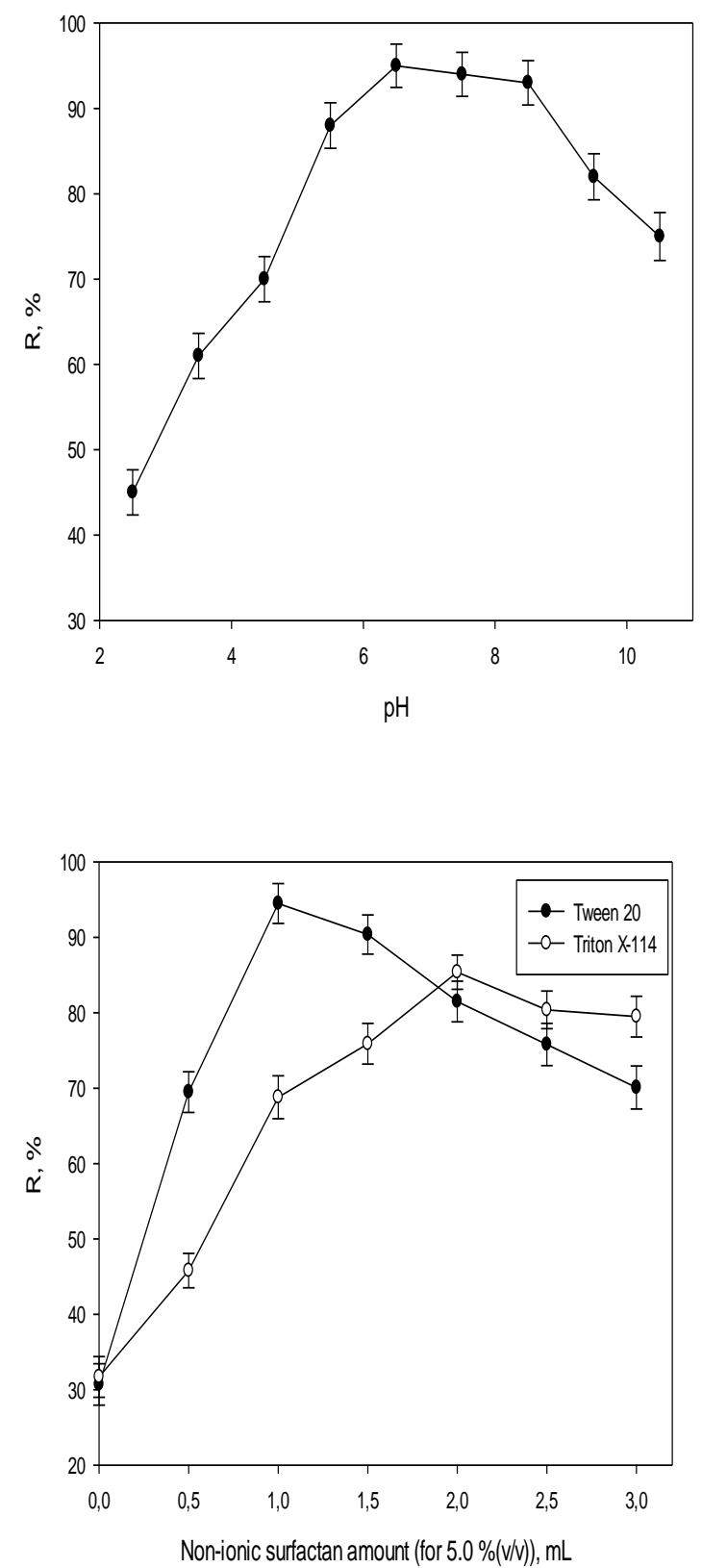

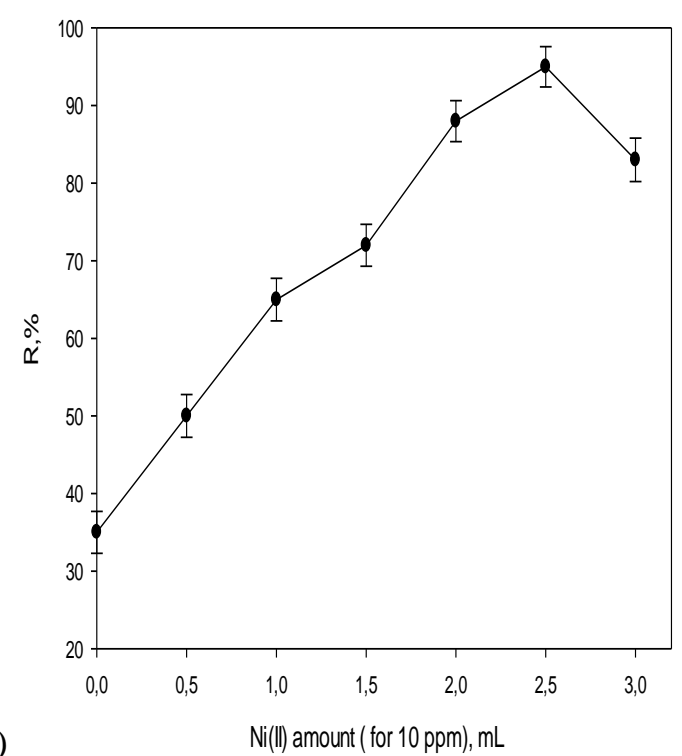

(b)

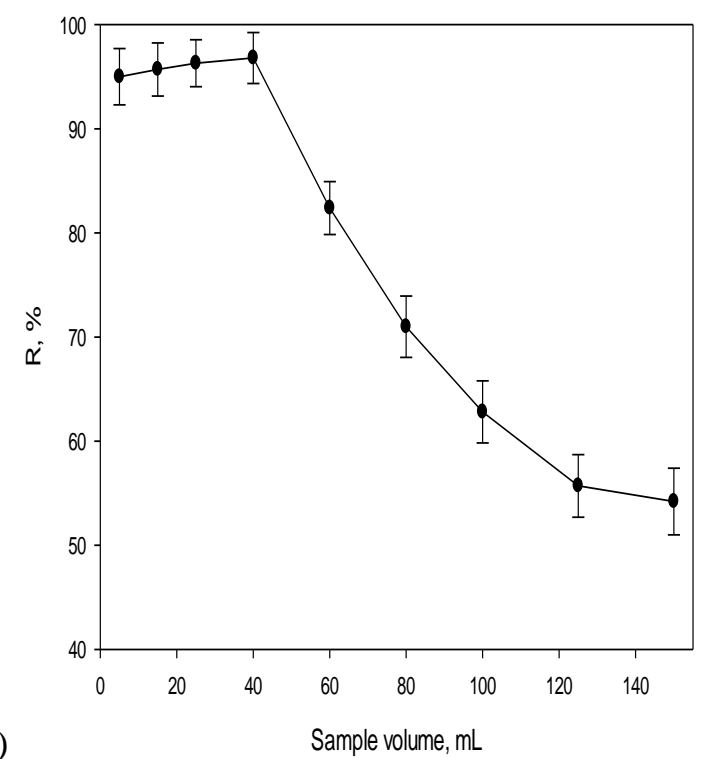

(d)

Figure 2 (a-d). Optimization study of some parameters affecting the extraction method 
Preliminary experiments were carried out at $\mathrm{pH} 6.5$ with some transition metal ions such as $\mathrm{Cu}$ (II), $\mathrm{Fe}$ (III) and Ni (II) in equal molar concentrations to form a chelate complex at the appropriate and sufficient consistency with the carmine in the phosphate-citrate buffer. It has been found that the best chelate complex formation and phase separation are obtained in a manner that gives maximum sensitivity when $\mathrm{Ni}(\mathrm{II})$ is used. This is due to the coordination of the positive charge of the $\mathrm{Ni}$ (II) ion with the phenol and keto groups of the ligand as a result of the concentration-dependent displacement-based complex formation with the $\mathrm{Al}(\mathrm{OH}) \mathrm{L}_{2}{ }^{2-}$ (Which can give ionic and stable metal complexes with pKa values of 2.81, 5.43 and 8.10) can be explained by the formation of chelates as a result of the decrease of the polarity of the $\mathrm{Ni}$ (II) ion [31].

$\mathrm{Ni}^{2+}+$ HCitrate $^{3-} \rightarrow$ NiHCitrate', a stability constant of about 5.11

$\mathrm{Al}(\mathrm{OH}) \mathrm{L}_{2}{ }^{2-}+\mathrm{NiHCitrate}^{-} \rightarrow \mathrm{NiL}_{2}{ }^{2-}+\mathrm{Al}(\text { Citrate })^{-}$
$+\mathrm{H}_{2} \mathrm{O}$

$\mathrm{NiL}_{2}{ }^{2-}+2 \mathrm{H}_{2} \mathrm{O} \rightarrow \mathrm{H}_{2} \mathrm{NiL}_{2}+2 \mathrm{OH}^{-}$

As a consequence of the increased acidity of the complex over the critical micelle concentration (CMC), the $\mathrm{H}_{2} \mathrm{NiL}_{2}$ chelate complex will readily pass through the surfactant-rich surfactant complex in a hydrophobic interaction with the hydroxyl and polar ethoxy groups of Tween 20 . Then, the effect of the amount of $\mathrm{Ni}$ (II) in the constant concentration $\left(10 \mathrm{mg} \mathrm{L}^{-1}\right)$ of carmine in $\% \mathrm{GC}$ was investigated between $0.0-3.0 \mathrm{~mL}$, keeping other parameters constant. As can be seen from Figure 2 (b), the $\% \mathrm{R}$ is about $35 \%$ in the absence of $\mathrm{Ni}$ (II), but increases rapidly with increasing $\mathrm{Ni}$ (II) content. When $2.5 \mathrm{~mL}$ of the $\mathrm{Ni}$ (II) solution was used, the $\% \mathrm{R}$ value was not quantitatively $(\sim 95 \%)$. On the other hand, in the presence of higher Ni (II), a decrease in $\% \mathrm{R}$ was observed because the excess of Ni (II) ions pass into the surfactant phase. For these reasons, $2.5 \mathrm{~mL} \mathrm{Ni}$ (II) solution was used for carmine extraction in subsequent studies.
Surfactant concentration and species are critical factors to shift to the surfactant phase of the resulting Carmine-Ni complex and should be sufficient for the quantitative extraction of the analyte. In addition, as the non-ionic surfactant volume increases, a more efficient mass transfer from the sample solution to the surfactant-rich phase can be expected. Therefore, in order to obtain the highest possible recovery value, the extraction procedure should be carefully investigated to identify the minimum required surfactant volume. For this purpose, the effect of Tween 20 and Triton $\mathrm{X}-114$ non-ionic surfactants on carmine recovery was investigated at a constant concentration (5\%, $\mathrm{w} / \mathrm{v}$ ) in the range of 0.0-3.0 mL. As can be seen in Figure 2 (c), the best recovery was obtained when $1.0 \mathrm{~mL}$ of Tween 20 was used. As the volume of the surfactant-rich phase obtained after centrifugation is increased, the dilution agent in the higher volumes is used. Therefore, the final volume has increased. Hence, in subsequent experiments $1.0 \mathrm{~mL}$ of $5.0 \%(\mathrm{w} / \mathrm{v}$ ) Tween 20 was used to achieve good phase separation and high recovery.

Optimization of sample volume is important for both the sensitivity and the enrichment factor because carmine is found in trace quantities in food samples. The effect of sample volume on the recovery of carmine was investigated under optimum conditions from $5 \mathrm{~mL}$ to $150 \mathrm{~mL}$ and the obtained data is given in Figure 2 (d). The results of the study show that extraction after $40 \mathrm{~mL}$ of sample volume is reduced. For this reason, the enrichment factor was calculated as 80 with the highest sample volume $(40 \mathrm{~mL})$ to final volume $(500 \mu \mathrm{L})$.

Ultrasonic time is an important parameter to accelerate the surfactant mass transfer. The time required for the two phases (aqueous phase and surfactant phase) to reach equilibrium is called the extraction time. The effect of ultrasonic time on the $\%$ GK was investigated for 1 to 30 minutes by applying ultrasonic power to the same specimens $(300 \mathrm{~W}, 40 \mathrm{kHz})$. From studies, mass transfer is not 
quantitatively complete, so it can be said that the \% $\mathrm{R}$ was very low when the duration of sonication was below 5 minutes. The best recovery was achieved within 10 minutes and no significant change in recovery was observed for longer periods. In subsequent studies, 10 min was selected as the ultrasound duration for carmine extraction.

The temperature may facilitate clouding by affecting the water solubility of the extracting nonionic surfactant (Tween 20). Furthermore, in extractions experiments, the temperature of the experimental environment must be above its clouding temperature in order for the surface-active material used to obtain a cloudy appearance, or clouding does not occur. For this reason, the effect of equilibrium temperature on recovery is investigated under optimum conditions from room temperature to $70^{\circ} \mathrm{C}$. At temperatures lower than $55^{\circ} \mathrm{C}$, the phase separation is very low as cloud formation is not complete. At higher temperatures, there was no phase separation due to possible degradation of the complex inverse. For this reason, the optimum equilibrium temperature for extraction of carmine was $55^{\circ} \mathrm{C}$ in subsequent studies.

After subjecting the test tubes to centrifugation at $4000 \mathrm{rpm}$ for 5 minutes, the resulting surfactant rich phase was highly viscous and low in volume. For this reason, the final volume of the phase prior to spectrophotometric determination was set to 500 $\mu \mathrm{L}$ with methanol.

\subsection{Selectivity study}

After optimizing the variables that could affect the extraction, the selectivity of the selected chemical medium was tested. Method selectivity is very important for carmine extraction. As the method is developed using model solutions, potential chemical species in food samples can reduce recovery by affecting carmine's complex formation. For this reason, a wide range of intervention studies have been conducted and tolerance limits and recovery values have been determined for each species. The tolerance limit is defined as the ratio of the concentration to the concentration of carmine in the entrepreneurial analytical signal that causes a failure of less than \pm $5 \%$. It is clear that there is no significant interference effect as shown in Table 2. In short, the proposed method has a high tolerance limit for foreign ions and can be reliably applied to the identification and extraction of carmine in food samples.

Table 2. Effect of possible interfering species on the extraction efficiency of carmine

\begin{tabular}{ccc}
\hline Foreign Ions & $\begin{array}{c}\text { Tolerance } \\
\text { Limit }\end{array}$ & Recovery, \% \\
\hline $\mathrm{Cd}^{2+}$ & 1000 & 102.1 \\
$\mathrm{Mg}^{2+}$ & 1000 & 97.7 \\
$\mathrm{Al}^{3+}$ & 1000 & 98.5 \\
$\mathrm{Br}^{-}$ & 750 & 101.4 \\
$\mathrm{SO}_{4}{ }^{2-}$ & 750 & 96.9 \\
$\mathrm{Ag}^{+}$ & 750 & 96.7 \\
$\mathrm{Co}^{2+}$ & 750 & 96.8 \\
$\mathrm{~Pb}^{2+}$ & 500 & 102.5 \\
Tartrazine & 500 & 97.7 \\
$\mathrm{Amaranth}$ & 500 & 95.3 \\
Sudan (I-III) & 500 & 96.4 \\
$\mathrm{Cr}^{3+}$ & 250 & 103.9 \\
Brilliant Blue & 250 & 95.4 \\
Ponceau 4RC & 200 & 95.1 \\
$\mathrm{Cu}^{2+}$ & 100 & 95.0 \\
$\mathrm{Mn}^{2+}$ & 50 & 94.4 \\
$\mathrm{Zn}^{2+}$ & 50 & 93.7 \\
\hline
\end{tabular}

\subsection{Analytical features of proposed method}

The analytical properties of the method were tested in two different ways, after optimizing the variables that might affect the extraction process. First, a calibration equation using the model solution under optimum conditions, linear working range, limit of detection (LOD) and the limit of quantification (LOQ), the enrichment factor (EF), the relative standard deviation (\% RSD) and some analytical including recovery $\%$ parameters were determined. In the second study, the same analytical properties were found by matrix matching by adding carmine to sample solutions at different concentrations. Both studies were repeated five times.

Calculation graphs were generated for both model solutions and matched solutions and the slopes were compared with the Student t-test. For possible matrix effect, the matrix is $95 \%$ with the 
slopes of the matching standard curve, there is no significant difference between the model standard curve for confidence level and four degrees of freedom. The calculated t-factor (1.73) was below the critical Student's $t$ (2.78), so that calibration equation obtained using model solutions in the analysis of food products could be used reliably. The detail result was shown in Table 3.

Table 3. Analytical characteristics of the method for model solutions and matrices-matched solutions

\begin{tabular}{ccc}
\hline Analytical Features & For model solutions & For matrix-match solutions \\
\hline Calibration equation & $\mathrm{A}=8.25 \times 10^{-3}[$ carmine $]+3.21 \times 10^{-4}$ & $\mathrm{~A}=7.85 \times 10^{-3}[$ carmine $]+4.38 \times 10^{-4}$ \\
Linear range, $\mu \mathrm{g} \mathrm{L} \mathrm{L}^{-1}$ & $1.5-350$ & $2-300$ \\
Limit of detection $(\mathrm{LOD}, \mathrm{n}: 12$, & 0.4 & 1.1 \\
$\left.3 \sigma_{\mathrm{b}} / \mathrm{m}\right), \mu \mathrm{g} \mathrm{L}^{-1}$ & & 3.6 \\
$\begin{array}{c}\text { Limit of quantification (LOQ, } \\
\left.\mathrm{n}: 12,10 \sigma_{\mathrm{b}} / \mathrm{m}\right), \mu \mathrm{g} \mathrm{L}^{-1}\end{array}$ & 1.5 & 3.9 \\
Relative standard deviation & & \\
$(\% \mathrm{RSD})$ & 3.7 & $92.4-102.7$ \\
Recovery, $\%$ & $94.8-104.7$ & 80 \\
Preconcentration factor $(\mathrm{PF})$ & 80 & \\
\hline
\end{tabular}

Table 4. Results for the determination of carmine in food samples by the proposed method

\begin{tabular}{ccccc}
\hline Food Samples & $\begin{array}{c}\text { Added } \\
\left(\mu \mathrm{g} \mathrm{L}^{-1} \text { or } \mu \mathrm{g} \mathrm{kg}^{-1}\right)\end{array}$ & $\begin{array}{c}\text { Found } \\
\left(\mu \mathrm{g} \mathrm{L}^{-1} \text { or } \mu \mathrm{g} \mathrm{kg}^{-1}\right)\end{array}$ & $\begin{array}{c}\text { Recovery } \\
(\%)\end{array}$ & $\begin{array}{c}\text { RSD } \\
(\%)\end{array}$ \\
\hline \multirow{3}{*}{ Candy } & - & 120.7 & - & 2.6 \\
& 20 & 136.2 & 96.8 & 2.8 \\
Apricot jam & 50 & 167.3 & 98.0 & 3.2 \\
& - & 116.7 & - & 2.9 \\
Cherry jam & 20 & 140.1 & 103.1 & 3.1 \\
& 50 & 170.7 & 102.4 & 3.3 \\
Strawberry jam & - & 95.4 & - & 2.9 \\
& 20 & 110.2 & 95.5 & 3.1 \\
Powder beverage & 50 & 140.7 & 96.8 & 3.3 \\
(sour cherry) & - & 183.1 & - & 3.0 \\
& 50 & 198.8 & 97.5 & 3.2 \\
Powder beverage & - & 229.8 & 98.6 & 3.4 \\
(peach) & 50 & 195.8 & - & 3.1 \\
& - & 204.6 & 94.8 & 3.3 \\
Strawberry biscuit & 20 & 235.9 & 96.7 & 3.4 \\
& 50 & 145.6 & - & 2.8 \\
Banana biscuit & - & 158.3 & 95.9 & 2.9 \\
& 20 & 189.9 & 97.1 & 3.2 \\
Jelibon & 50 & 55.7 & - & 2.7 \\
& - & 77.7 & 102.6 & 28 \\
& 50 & 108.3 & 101.2 & 3.1 \\
& - & 30.8 & - & 2.4 \\
& 20 & 52.7 & 104.7 & 2.5 \\
& 50 & 82.8 & 102.5 & 2.7 \\
& & 125.5 & - & 2.8 \\
& 142.2 & 97.7 & 2.9 \\
& 10 & 173.0 & 98.6 & 3.1 \\
\hline
\end{tabular}




\subsection{Precision, accuracy and applications}

Since we do not have a certified reference material containing carmine, two different studies have been conducted to test the correctness and accuracy of the proposed method. The accuracy of the proposed procedure was evaluated by intra-day $(\mathrm{x})$ and inter-day (y) reproducibility studies. This process was performed as follows. For each study, three different carmine concentrations were added to the food samples and the results of three replicate analyses on three different days were calculated from the coefficient of variation $(\mathrm{CV}) \%=2^{(1-0.5 \mathrm{log}}$ C) from the Horwitz equation. ${ }^{32}$ Where $\mathrm{C}$ is concentration with $\mu \mathrm{g} \mathrm{L}^{-1}$ units. $\mathrm{CV}_{\mathrm{x}}$ and $\mathrm{CV}_{\mathrm{y}}$ were calculated as described in the ISO 5725-2 guidelines [32] and ranged between 1.8-3.4\% and 2.1-3.5\% respectively. All CVs, intra-day (7.2\%) and inter-day (11.3\%), It was below the maximum values allowed by the Horwitz equation. The proposed procedure has examined the correctness of the recovery process. This process was performed as follows. Two different carmine concentrations were added to each food sample, and then the general extraction procedure was applied to these samples for the carmine assay. Quantitative recovery values were obtained during the studies. This suggests that the correctness of the

proposed method has been tested safely. Detailed results are given in Table 4.

As is known, carmine is used as food dye. For this reason, food samples that are important for human health and that are consumed more are selected to test the analytical feasibility and reliability of the proposed method. Food samples were prepared for analysis as described in Section 2.3. 3.0 mL of the prepared samples were subjected to the recommended extraction procedure. The standard addition method was used to test for correctness during the analysis.

\subsection{Comparison with the other methods}

The contribution of the proposed method to the literature has been shown more clearly compared to other methods. The results are detailed in Table 5. As can be seen, it has been observed that the analytical properties obtained using this method are better or comparable to those of other methods. The present method has certain advantages such as low toxicity, simplicity and low cost compared to expensive, time consuming, complex but precise techniques which require a specialist user in his field such as HPLC-PDA, SWV and DPP.

Table 5. Comparison of analytical parameters of the proposed method with some of the methods reported in literature

\begin{tabular}{|c|c|c|c|c|c|c|}
\hline Samples & Method & LOD & liner range & $\begin{array}{l}\mathrm{RSD}, \\
\%\end{array}$ & $\begin{array}{c}\text { Recovery, } \\
\%\end{array}$ & Reference \\
\hline Foods & SE/HPLC & $\begin{array}{c}0.4 \mathrm{mg} \\
\mathrm{L}^{-1}\end{array}$ & $\begin{array}{c}1.0-100.0 \\
\mathrm{mg} \mathrm{L}^{-1}\end{array}$ & 6.8 & 94.1 & [33] \\
\hline $\begin{array}{l}\text { Ice cream and } \\
\text { soft drinks }\end{array}$ & SV & $\begin{array}{c}0.002 \mathrm{mg} \\
\mathrm{L}^{-1}\end{array}$ & $\begin{array}{c}0.05-0.14 \\
\mathrm{mg} \mathrm{L}^{-1}\end{array}$ & 2.2 & 97.2 & [34] \\
\hline $\begin{array}{l}\text { Confectionery } \\
\text { and milk }\end{array}$ & DPP & $\begin{array}{c}0.18 \mathrm{mg} \\
\mathrm{L}^{-1}\end{array}$ & $\begin{array}{c}1.1-100.5 \\
\mathrm{mg} \mathrm{L}^{-1}\end{array}$ & 7.8 & 95.0 & [35] \\
\hline Foods & Spectrophotometry & $\begin{array}{c}0.012 \mathrm{mg} \\
\mathrm{L}^{-1}\end{array}$ & $\begin{array}{c}0.04-5.0 \\
\mathrm{mg} \mathrm{L}^{-1}\end{array}$ & 4.0 & 100.0 & [36] \\
\hline Foods & Spectrophotometry & $0.4 \underset{1}{\mu} \mathrm{g} \mathrm{L}^{-}$ & $\begin{array}{c}1.5-350 \\
\mu \mathrm{g} \mathrm{L}^{-1}\end{array}$ & 3.7 & $94.8-104.7$ & $\begin{array}{l}\text { The } \\
\text { current } \\
\text { method }\end{array}$ \\
\hline
\end{tabular}

\section{CONCLUSION}

In this study, a simple, easy to use, low cost and environmentally friendly method for the carmine determination of food samples was developed using ultrasonically assisted extraction before spectrophotometric detection. The effects of the main parameters such as solution $\mathrm{pH}$, surfactant and metal concentration, ultrasonic time and temperature have been researched and optimized. After optimization of the experimental conditions, satisfactory results were obtained for the accuracy and precision of the method. According to our 
literature review, this study is one of a limited number of studies done spectrophotometric for ultrasound-assisted extraction of carmine for trace levels in food samples. The method is simple, sensitive, selective and environmentally friendly to determine carmine in food samples and also does not require complex techniques such as high performance liquid chromatography or stripping voltammetry. Therefore, this method can be safely applied to effectively monitor carmine in terms of food safety in food products.

\section{ACKNOWLEDGMENTS}

I would like to express my deeply thanks to Prof. Dr. Ramazan Gürkan and associate Prof. Dr. Nail ALTUNAY for their valuable suggestions, helpful comments and continual support throughout the research.

\section{REFERENCES}

[1] Hsiu-Mei C., Ting-Chien C., San-De P., Chiang, H. L., Adsorption characteristics of Orange II and Chrysophenine on sludge adsorbent and activated carbon fibers, Journal of Hazardous Materials, 161-2,3 (2009) 13841390.

[2] Dinç E, Baydan E., Kanbur M., Onur, F., Spectrophotometric multicomponent determination of sunset yellow, tartrazine and allura red in soft drink powder by double divisor-ratio spectra derivative, inverse leastsquares and principal component regression methods, Talanta, 58-3 (2002) 579-594.

[3] Watson D.H., Food chemical safety, volume 2: additives, Woodhead Publishing Limited, Abington Hall, Abington, Cambridge CB1 6AH, UK, (2002).

[4] Yilmaz U. T., Ergun F., Yilmaz H., Determination of the food dye carmine in milk and candy products by differential pulse polarography, Journal of Food and Drug Analysis, 22-3 (2014) 329-335.

[5] Alghamdi A.H., Alshammery H.M., Abdalla M.A., Alghamdi A.F., Determination of carmine food dye (E120) in foodstuffs by stripping voltammetry, Journal of AOAC
International, 92-5 (2009) 1454-1459.

[6] Silva T.A., Pereira G.F., Fatibello-Filho O., Eguiluz K.I.B., Salazar-Banda G.R., Electroanalytical sensing of indigo carmine dye in water samples using a cathodically pretreated boron-doped diamond electrode, Journal of Electroanalytical Chemistry, 769 (2016) 28-34.

[7] Heydari R., Hosseini M., Zarabi S., A simple method for determination of carmine in food samples based on cloud point extraction and spectrophotometric detection, Spectrochimica Acta Part A: Molecular and Biomolecular Spectroscopy, 150 (2015) 786-791.

[8] González M., Méndez J., Carnero A., Lobo M.G., Afonso, A., Optimizing conditions for the extraction of pigments in cochineals (Dactylopius coccus Costa) using response surface methodology, Journal of Agricultural and Food Chemistry, 50-24 (2002) 6968-6974.

[9] Yilmaz U.T., Ergun F., Yilmaz, H., Determination of the food dye carmine in milk and candy products by differential pulse polarography, Journal of Food and Drug Analysis, 22-3 (2014) 329-335.

[10] Zhang L., Wang H., Cao, J., Determination of carmine, allura red and erythrosine in meat product by high performance liquid chromatography, Journal of Food Safety and Quality, 7-3 (2016) 1006-1010.

[11] Qi P., Zeng T., Wen Z., Liang X., Zhang X., Interference-free simultaneous determination of Sudan dyes in chili foods using solid phase extraction coupled with HPLC-DAD, Food Chemistry, 125-4 (2011) 1462-1467.

[12] Soylak M., Unsal Y. E., Yilmaz E., Tuzen, M., Determination of rhodamine B in soft drink, waste water and lipstick samples after solid phase extraction, Food and Chemical Toxicology, 49-8 (2011) 1796-1799.

[13] Altunay N., Gürkan, R., A new cloud point extraction procedure for determination of inorganic antimony species in beverages and biological samples by flame atomic absorption spectrometry, Food Chemistry, 175 (2015) 507515.

[14] Gürkan R., Korkmaz S., Altunay N., Preconcentration and determination of vanadium and molybdenum in milk, vegetables 
and foodstuffs by ultrasonic-thermostaticassisted cloud point extraction coupled to flame atomic absorption spectrometry, Talanta, 155 (2016) 38-46.

[15] Altunay N., Gürkan R., Orhan U., A new ultrasonic-assisted cloud-point-extraction procedure for pre-concentration and determination of ultra-trace levels of copper in selected beverages and foods by flame atomic absorption spectrometry, Food Additives \& Contaminants: Part A, 32-9 (2015) 1475-1487.

[16] Elik A., Altunay N., Gürkan R., Determination of trace levels of nitrite in beverages samples through micellar improved catalytic kinetic spectrophotometry, Cumhuriyet Sci. J., 38-3 (2017) 400-411.

[17] Zaghdoudi K., Pontvianne S., Framboisier X., Achard M., Kudaibergenova R., Ayadi-Trabelsi M., Guiavarc Y., Accelerated solvent extraction of carotenoids from: Tunisian Kaki (Diospyros kaki L.), peach (Prunus persica L.) and apricot (Prunus armeniaca L.), Food Chemistry, 184 (2015) 131-139.

[18] Xia X., Zhu C., Luo J., Zeng Z., Guan C., Ng C. F., Fan H. J., Synthesis of Free-Standing Metal Sulfide Nanoarrays via Anion Exchange Reaction and Their Electrochemical Energy Storage Application. Small, 10-4 (2014) 766773.

[19] Hong J. G., Zhang B., Glabman S., Uzal N., Dou X., Zhang H., Chen Y., Potential ion exchange membranes and system performance in reverse electrodialysis for power generation: a review, Journal of Membrane Science, 486 (2015) 71-88.

[20] Gürkan R., Altunay N., Quantification of 5hydroxymethylfurfural in honey samples and acidic beverages using spectrophotometry coupled with ultrasonic-assisted cloud point extraction, Journal of Food Composition and Analysis, 42 (2015) 141-151.

[21] Altunay N., Gürkan R., Sertakan K., Indirect determination of free, total, and reversibly bound sulfite in selected beverages by spectrophotometry using ultrasonic-assisted cloud point extraction as a preconcentration step, Food Analytical Methods, 8-8 (2015) 2094-2106.
[22] Pourreza N., Sharifi H., Golmohammadi H., Curcumin nanoparticles combined with cloud point extraction for citrate determination in food and drug samples, Microchemical Journal, 129 (2016) 213-218.

[23] Oh J. Y., Choi S. D., Kwon H. O., Lee S. E., Leaching of polycyclic aromatic hydrocarbons (PAHs) from industrial wastewater sludge by ultrasonic treatment, Ultrasonics Sonochemistry, 33 (2016) 61-66.

[24] Lin S., Zhou X., Ge L., Ng S. H., Zhou X., Chang, V.W.C., Development of an accelerated leaching method for incineration bottom ash correlated to toxicity characteristic leaching protocol, Electrophoresis, 37-19 (2016) 24582461.

[25] Doche M.L., Mandroyan A., MouradMahmoud M., Moutarlier V., Hihn J.Y., An ultrasonic-assisted process for copper recovery in a des solvent: Leaching and re-deposition, Chemical Engineering and Processing: Process Intensification, 121 (2017) 90-96.

[26] Güney M., Elik A. Comparison of probe with bath ultrasonic leaching procedures for preparation to heavy metal analysis of biocollectors prior to atomic absorption spectrometry, Communications in Soil Science and Plant Analysis, 48-15 (2017) 1741-1752.

[27] Kakavandi M.G., Behbahani M., Omidi F., and Hesam G., Application of ultrasonic assisteddispersive solid phase extraction based on ionimprinted polymer nanoparticles for preconcentration and trace determination of lead ions in food and water samples, Food Analytical Methods, 10-7 (2017) 2454-2466.

[28] Dağdeviren S., Altunay N., Sayman,Y., Gürkan R., A new method of UA_CPE coupled with spectrophotometry for the faster and costeffective detection of proline in fruit juice, honey, and wine, Food Chemistry, 255 (2018) $31-40$.

[29] Lim H. S., Choi J. C., Song S. B., Kim M., Quantitative determination of carmine in foods by high-performance liquid chromatography, Food Chemistry, 158 (2014) 521-526.

[30] Kunkely H., Vogler A., Absorption and luminescence spectra of cochineal, Inorganic Chemistry Communications, 14-7 (2014) 1153- 
1155.

[31] Wyrzykowski D., Chmurzyński L., Thermodynamics of citrate complexation with $\mathrm{Mn}^{2+}, \mathrm{Co}^{2+}, \mathrm{Ni}^{2+}$ and $\mathrm{Zn}^{2+}$ ions, Journal of Thermal Analysis and Calorimetry, 102-1 (2009) 61-64.

[32] Goscinny S., Hanot V., Halbardier J.F., Michelet J. Y., Van Loco J., Rapid analysis of melamine residue in milk, milk products, bakery goods and flour by ultra-performance liquid chromatography/tandem mass spectrometry: From food crisis to accreditation, Food Control, 22-2 (2011) 226-230.

[33] Lim H. S., Choi J. C., Song S. B., Kim M., Quantitative determination of carmine in foods by high-performance liquid chromatography, Food Chemistry, 158 (2014) 521-526.

[34] Alghamdi A.H., Alshammery H.M., Abdalla M.A., Alghamdi A.F., Determination of carmine food dye (E120) in foodstuffs by stripping voltammetry, Journal of AOAC International, 92-5 (2009) 1454-1459.

[35] Yilmaz U.T., Ergun F., Yilmaz H., Determination of the food dye carmine in milk and candy products by differential pulse polarography, Journal of Food and Drug Analysis, 22-3 (2014) 329-335.

[36] Heydari R., Hosseini M., Zarabi, S.A., simple method for determination of carmine in food samples based on cloud point extraction and spectrophotometric detection, Spectrochimica Acta Part A: Molecular and Biomolecular Spectroscopy, 150 (2015) 786-791. 